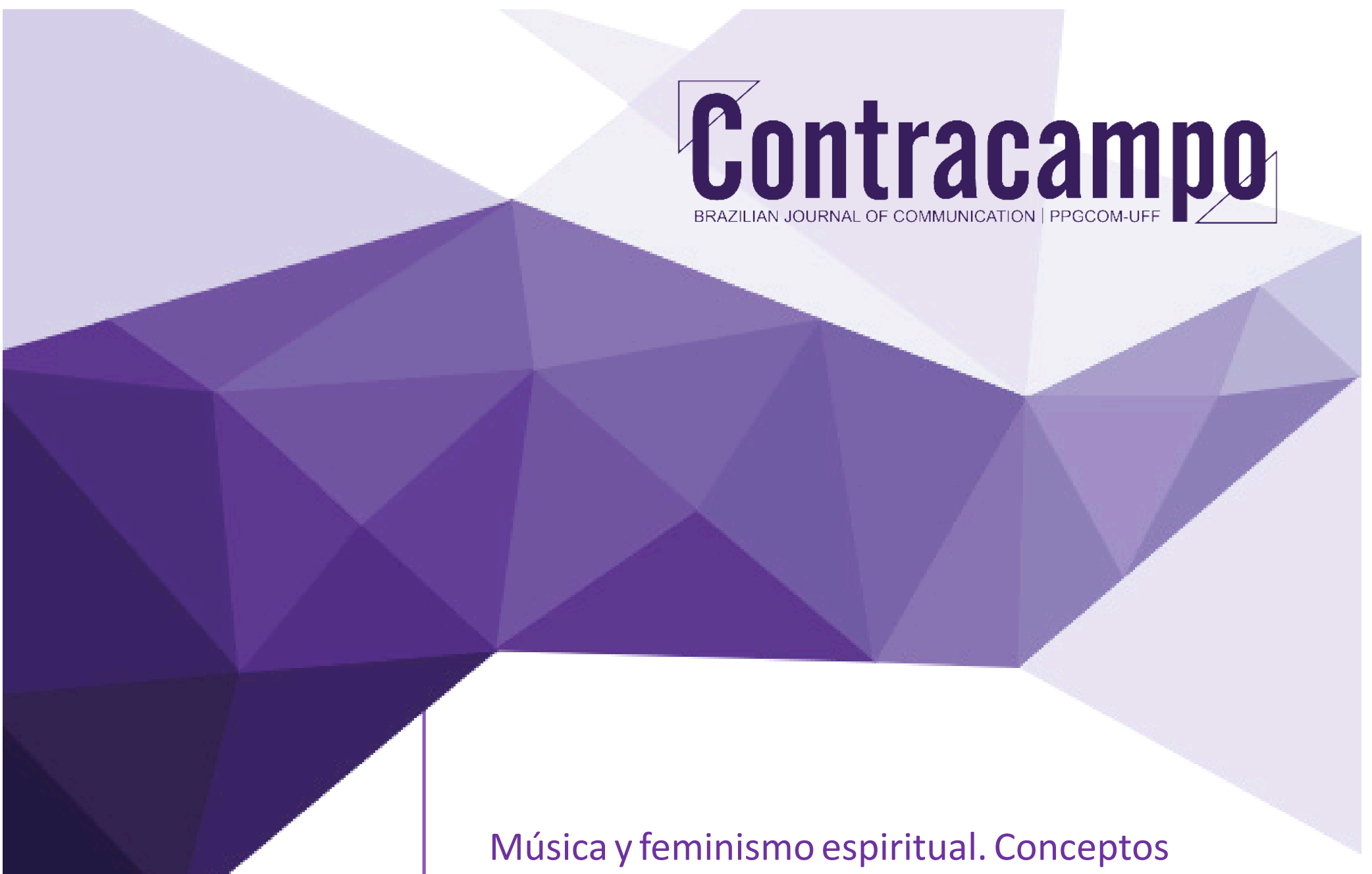

Música y feminismo espiritual. Conceptos

y estéticas religiosas en propuestas

musicales recientes de artistas mujeres

Edição v. 38

número 1 / 2019

Contracampo e-ISSN 2238-2577 Niterói (RJ), 38 (1)

abr/2018-jul/2018

A Revista Contracampo é uma revista eletrônica do Programa de Pós-Graduação em Comunicação da Universidade Federal Fluminense e tem como objetivo contribuir para a reflexão crítica em torno do campo midiático, atuando como espaço de circulação da pesquisa e do pensamento acadêmico.
Music and spiritual feminism. Religious concepts and aesthetics in recent musical proposals by women artists

\section{MERCEDES LISKA}

Doctorado en Ciencias Sociales en la Universidad de Buenos Aires. Investigadora del CONICET (Consejo Nacional de Investigaciones Científicas y Técnicas) y trabaja en el Instituto Gino Germani (UBA) y es docente en la Carrera de Ciencias de la Comunicación (UBA) y en el Conservatorio Manuel de Falla. Email: mmmliska@gmail.com. ORCID: https://orcid. org/0000-0001-9692-6446

AO CITAR ESTE ARTIGO, UTILIZE A SEGUINTE REFERÊNCIA:

\title{
PPG|COM UUFF
}

LISKA, Mercedes. Música y feminismo espiritual. Conceptos y estéticas religiosas en propuestas musicales recientes de artistas mujeres. Contracampo, Niterói, v. 38, n.1, p. 122-142, abr.-jul. 2019. 
Resumen

El feminismo espiritual aparece en las propuestas de diversas artistas mujeres de la música popular latinoamericana de creación reciente. La búsqueda de crecimiento o bienestar personal, y de soluciones a diversos problemas sociales, canalizada en la invocación de virtudes y poderes femeninos ancestrales, se manifiesta en el lenguaje poético o temático de canciones, en la composición visual, audiovisual y performática de los recitales. Un conjunto de representaciones religiosas presentes en distintas estéticas musicales que apuntan a visualizar poderes femeninos silenciados por el sistema patriarcal. Este trabajo analiza las formas estéticas en las que aparecen representadas prácticas y narrativas de espiritualidad en cuatro propuestas de artistas argentinas y las pone en relación con algunos elementos presentes en los discursos políticos contemporáneos.

\section{Palabras clave}

feminismo espiritual; músicas argentinas; estéticas religiosas; movimiento de mujeres

\section{Abstract}

The spiritual feminism appears in the proposal of diverse women artists of Latin American popular music created recently. References linked to personal and social growth and well-being, to energy balance and the ancestral feminine powers, that are manifested in the poetic and thematic language of songs, in the visual, audiovisual and performative composition of the recitals. A set of multi religious representations present in different musical aesthetics contribute to visualize female powers silenced by the patriarchal system. This paper analyzes the aesthetic forms in which practices and narratives of spirituality are represented in four proposals of Argentine female artists, and it puts them in relation to some of the speeches of the contemporary political scene.

\section{Key words}

spiritual feminism; Argentine female musicians; religious aesthetics; women's movement 


\section{Presentación}

...la caza de brujas estaba arraigada en las transformaciones sociales que acompañaron el surgimiento del capitalismo. Silvia Federici, Calibán y la bruja, 2015.

En la música reciente realizada por mujeres se reiteran referencias de espiritualidad, un término de creciente diseminación en los discursos sociales contemporáneos. Dicha noción alude a un conjunto variado de prácticas, creencias o sentidos cosmogónicos que son recuperados tanto en su dimensión simbólica como estética. Este repertorio de improntas religiosas aporta, junto a otras propuestas artísticas y musicales, imaginarios de una feminidad reposicionada en un momento bisagra en las políticas de género y sexualidad en la Argentina, así como en otros países de Latinoamérica.

Las nociones de espiritualidad que aparecen en las creaciones de varias artistas se relaciona con narrativas de una historia ancestral y popular de las mujeres, y con ella, la vuelta a una percepción religiosa de la experiencia musical en contextos culturales generalmente seculares como lo son los géneros modernos de la música popular argentina.

Dichas recreaciones hacen eje en la interpretación del canto, asociada a diferentes actividades que se volvieron habituales entre mujeres de clase media de entornos socioculturales heterogéneos; la temática del descubrimiento personal y el trabajo sobre uno mismo abarca grupos y prácticas espirituales que desafían el pensamiento iluminista y la separación entre religión (alma) y psicología (mente). Estas actividades se ven reflejadas, entre otras, en la gestación del neo-hinduismo, el neochamanismo, el cristianismo mágico que reivindica el Espíritu Santo, o en el movimiento Nueva Era (Viotti y Felitti 2016).

En el desarrollo de una investigación sobre las experiencias musicales actuales de artistas argentinas, y de puntualmente analizar los rasgos estéticos de sus trabajos, se observó la dimensión espiritual como un tópico constante que se distingue de los estilos y proyectos musicales liderados por músicos varones. ${ }^{1}$ La dimensión espiritual a la que hacemos referencia se presenta en la expresividad corporal, en la ambientación y ritualización de recitales, en símbolos de connotación religiosa que aparecen en la producción audiovisual, e incluso, en la temática de las canciones. Las estéticas mágico-religiosas aparecen, por un lado, en propuestas que combinan otras tantas referencias y tópicos culturales, y de modo más acotado son centrales y definen el estilo de la propuesta artística.

Mediante recursos líricos, sonoros y visuales la producción musical involucra las experiencias de conversión espiritual de las propias artistas; procesos de transformación y cambio en su modo de vida, las alternativas y soluciones a problemas de desestabilización emocional o desatención personal, las búsquedas profesionales conectadas con los sentimientos, deseos o anhelos trascendentes, y la gestión económica autónoma. En algunos casos las estéticas musicales espirituales están en relación con otras actividades de las artistas, como la guía de encuentros de mujeres en torno a dinámicas de los círculos, en los cuales el canto ocupa funciones fundamentales de comunicación y de sanación.

A su vez, si la espiritualidad es un aspecto que se reitera en los trabajos recientes de artistas argentinas, también aparece en las producciones de artistas de otros países de América Latina, incluso en músicas que se difunden en la cultura de masas a través del pop latino y afro-norteamericano.

Estos rasgos temáticos aparecen dentro de un abanico de contenidos mucho más amplio que configuran representaciones de género y sexualidad en artistas de una generación intermedia en proceso de consolidación profesional. Estas apuestas creativas configuran una etapa de desarrollo musical de parte

${ }^{1}$ Este trabajo forma parte de un proyecto de investigación que se titula "Bien Warrior. Un análisis sobre la producción artística de mujeres en la música popular" iniciado en el año 2016 en el Instituto de Investigaciones Gino Germani de la Universidad de Buenos Aires, solventado por el Consejo de Investigaciones Científicas y Técnicas (CONICET). 
de mujeres favorecida por un mayor reconocimiento y valoración artística, una respuesta que tiene que ver con un cambio de percepción del género como ordenador de la actividad profesional. ${ }^{2}$

Este trabajo realiza una descripción de las referencias espirituales en distintas artistas y los sentidos sociales que movilizan en el contexto de masificación de la lucha por las violencias y desigualdades que afectan a las mujeres. ¿Qué funciones cumplen las narrativas espirituales actuales en Argentina y América Latina?, ¿Cómo se relacionan con los procesos culturales que involucran a las mujeres?, ¿Cómo se manifiestan en la actividad musical?

Vamos a analizar cuatro proyectos musicales: Miss Bolivia, Paloma del Cerro, Perotá Chingó y La Yegros. Estos abordan diferentes estilos musicales: desde géneros anglo-caribeños como el reggae o el hip hop norteamericano, a los repertorios tradicionales del folclore latinoamericano combinados con texturas electrónicas. Las propuestas musicales en su conjunto dan cuenta de un abanico heterogéneo de abordajes de lo espiritual, y de la centralidad de las representaciones religiosas en una porción significativa de la música popular urbana contemporánea de Argentina. Analizaremos la biografía y trayectoria artística de cada una en cruce con la caracterización de algunas de sus canciones, artes visuales en redes, difusión y portadas de discografía, videoclips, propuesta de los recitales y otras situaciones establecidas en el intercambio con el público, así como los testimonios verbales de las artistas en entrevistas periodísticas. Dichos materiales son observados desde la mirada de los estudios culturales, las consideraciones teórico-metodológicas de Simon Frith de concebir lo musical en sus dimensiones múltiples y de entenderla como espacio de creación de sentidos sociales y no reflejo de su contexto y de su tiempo (Frith, 2014), la concepción marxista-gramsciana de la lucha en y por significar la cultura (Hall, 1984) y la perspectiva feminista de los estudios culturales (Hollows, 2005). Luego de las descripciones de lo observado en el ámbito musical, analizamos los rasgos espirituales en su conjunto reponiendo algunos debates sobre el feminismo espiritual por parte de la sociología de las religiones en Argentina (Frigerio, 2007; Viotti y Funes, 2015; Viotti y Felitti,2016 y Funes).

\section{Miss Bolivia}

María Paz Ferreyra lidera Miss Bolivia, una de las artistas locales de gran repercusión en los últimos años que partió de la realización independiente hasta lograr resonancia en la comunicación masiva. En el caso particular de esta artista es interesante ver la trayectoria que viene definiendo su música alrededor de temáticas de género y de un imaginario femenino desafiante de la hegemonía patriarcal.

Desde este perfil artístico, de fuerte significación política, Ferreyra introdujo las temáticas de nuevas espiritualidades en su trabajos musicales de 2017. Ese año presentó un nuevo disco: Pantera. Dos canciones de este trabajo remiten a conceptos espirituales, aunque esta impronta atraviesa el clima general del disco, asociado a un momento personal de la artista. Si bien se enmarca en el tono y la retórica de lucha del movimiento de mujeres que en Argentina ocupó masivamente las calles en junio de 2015, con el cual se muestra permanentemente identificada, Ferreyra establece un correlato entre lo social y su historia de vida. Pantera, el cuarto disco de Miss Bolivia, se inscribe en la densidad de la consigna que reza que lo personal es político.

Antes de este disco Miss Bolivia venía acompañando las reivindicaciones de género y diversidad sexual, de hecho es una de las referentes artísticas y político/culturales de su generación (intermedia) en la Argentina. Sin embargo, lo venía haciendo desde un estilo contracultural habitualmente identificado con el rock. En el arte visual que acompañó la difusión de Pantera, Ferreyra se muestra con una estética renovada,

2 Entre los años 2017 y 2018 se difundieron en los medios de comunicación una serie de trabajos estadísticos en el país que muestra la escasa participación de mujeres en las grillas de programación de los festivales de todo el país. De esos trabajos surgió la iniciativa de un proyecto de ley de cupo femenino que aspira a establecer un piso de $30 \%$ de participación en dichos eventos: https://indiehoy.com/noticias/ presentan-proyecto-ley-cupo-femenino-festivales-argentina/ 
más prolija, de tonos claros y azules de mucha iluminación en su cara y figura, y sus dreadlocks más ocultas. El mismo año de la salida de Pantera, Ferreyra contrajo matrimonio legal y dijo en los medios, que la interrogaron asombrados, que le había dado "cabida al amor", encontrando la estabilidad emocional deseada. ${ }^{3}$ Pantera recoge ese momento de plenitud de la artista asociado con un trabajo personal llevado a cabo a partir de la meditación, nutrición y otras técnicas concernientes al cuidado del cuerpo y el yo emocional.

"El Paso" y "Calma y respira" son los títulos de canciones del disco que apuntan a la utilización de recursos terapéuticos alternativos para encontrar bienestar o equilibrio emocional. La primera, en tiempo y clima pausado y descargas de acentuación grave en tiempos fuertes, habla de momentos de profundo dolor y angustia, que reitera como un mantra las dos palabras que titulan el tema y que aluden a las técnicas de meditación y que Paz Ferreyra lleva tatuadas en los brazos [ver imagen 1];

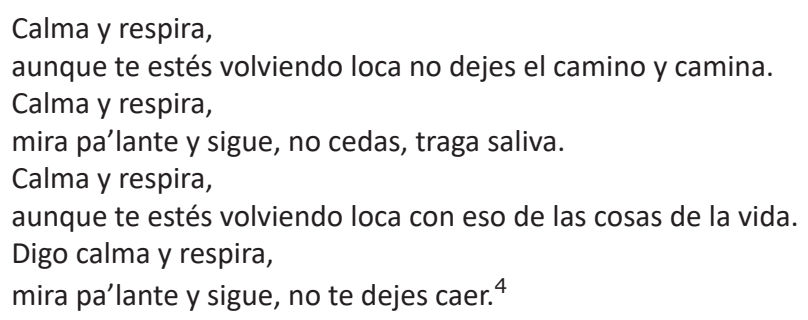

Varias de las canciones de Miss Bolivia hablan de situaciones personales de angustia, pero en esta canción la tristeza propia aparece en un segundo plano. Aquí ella le habla a una mujer angustiada, la acompaña con esta canción a pueda atravesar ese dolor para que no se deje caer. Le propone que modifique algo de su vida para cambiar la energía, limpiar el karma y concentrarse en la respiración;

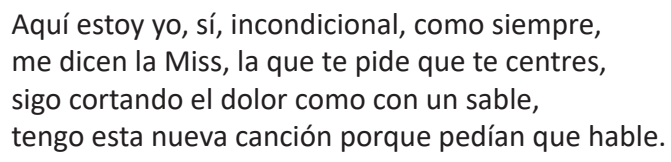

Esta canción de clima introspectivo marca una distancia respecto al resto de las canciones del disco y del estilo de Miss Bolivia, nutrido de música para bailar, y por esto mismo no aparece en el repertorio de los recitales. La segunda canción mencionada, "El Paso", contiene las características de la música más representativa de la artista y fue el primer corte del disco que produjo un videoclip. Los consejos de "Calma y respira" en esta canción aparecen en otra clave, haciendo referencia concreta a un espectro variado de técnicas y terapias de apoyo personal tales como el tarot, el yoga, el psicoanálisis y la astrología. Con una sonoridad de cumbia argentina, la letra narra la experimentación de recursos para sostener el equilibrio emocional, mejorar la sensación de bienestar y alejarse de los excesos como drogas y alcohol; 5

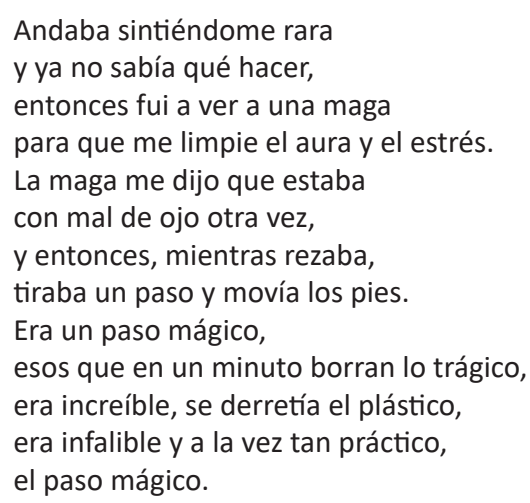

\footnotetext{
3 Programa de televisión en el que habla de su casamiento: https://www.youtube.com/watch?v=288Yicz3gQA

4 Audio en línea de "Calma y respira": https://www.youtube.com/watch?v=vgc6vT lihs

5 Audio en línea de "El paso": https://www.youtube.com/watch?v=oUTs3 IsCp0
} 
Esta canción también habla de energías, en este caso referidas a la limpieza de malas vibras. Una mujer-maga posee la habilidad o el don de curación mediante ritos de sanación que involucran la danza: "Me fui de la maga con un nuevo recurso...", continúa la canción. En el videoclip, "El Paso" se vuelve imágenes que apoyan y explicitan lo que dice la letra pero añade algunas referencias más, como por ejemplo al inicio del video cuando Ferreyra se despierta y la cámara hace foco en una escultura de lemanjá ubicada a su lado [ver imagen 2]. ${ }^{6}$ La deidad femenina por antonomasia del candomblé se conjuga con la imagen de la maga en el video: una mujer afrodescendiente con vestimentas religiosas tradicionales de color blanco. Los comentarios del video en Youtube, señalan la recepción de la canción en los mismos términos espirituales: "este tema lo escuché por primera vez de casualidad un día que tuve un ataque de pánico y los médicos me diagnosticaron estrés. Fue como una señal para mi... cada vez que lo escucho me levanta el ánimo!!! genia miss bolivia", "genia!!!! te adoro!!!! esta canción me salva de todos mis demonios. Sos una kapa!", "Sos una genia Paz!!! que siga la buena vibra".

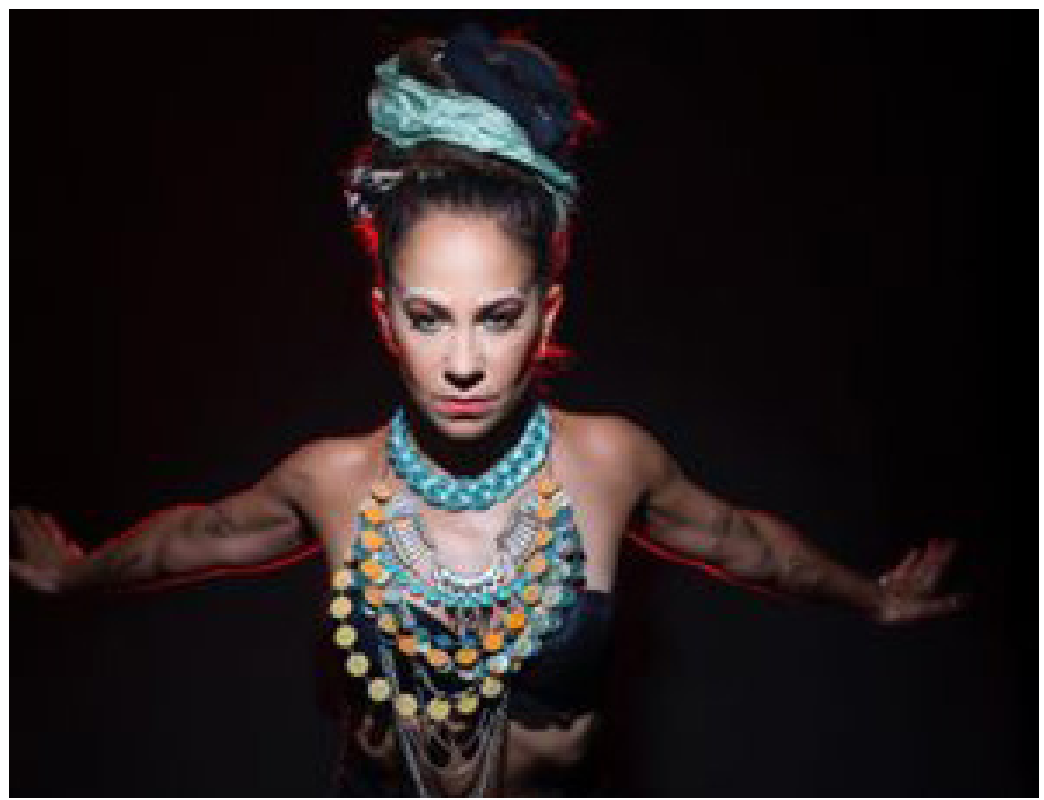

Imagen 1. Miss Bolivia; una de las imágenes de difusión en redes de la edición de su último trabajo discográfico, Pantera, 2017.

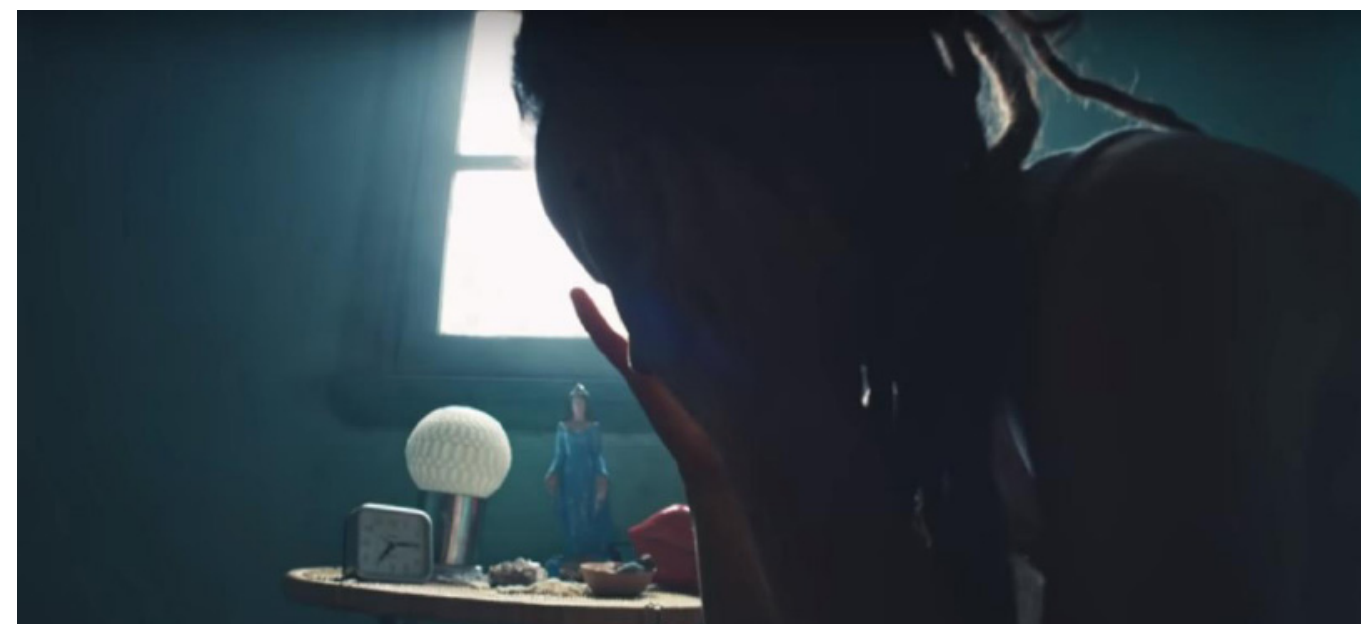

Imagen 2. Miss Bolivia; screenshot del videoclip de la canción "El Paso".

\footnotetext{
6 Videoclip de la canción "El Paso": https://www.youtube.com/watch?v=oQjDSmzxhEw
} 


\section{Paloma del Cerro}

Paloma del Cerro es el nombre artístico de un conjunto liderado por una cantante y compositora que comenzó la actividad profesional en la música alrededor del 2010. Como Paloma Kippes, anteriormente se dedicaba al diseño gráfico en cine y publicidad: "Estaba en España, trabajando como productora publicitaria, con seis meses de contrato. Ganaba muy buena plata, pero algo interno me decía No es esto."7 Entonces decidió, como ella dice, "soltar". 8

Sus trabajos musicales tuvieron una buena recepción del público y pronta visibilidad. En 2011 editó su primer disco, Gozar hasta que me ausente, junto a Gerardo "Grod" Morel, en el cual exploran posibilidades musicales desde la experimentación expresiva alrededor de las formas más tradicionales del folclore argentino combinado con electrónica: “Una simple melodía puede sacarte del flujo de pensamientos y transportarte al camino sagrado", puede leerse en la presentación escrita del disco físico.

En 2012 tuvo paralelamente un grupo de música devocional, Volver Acero, junto a otros dos músicos, Rodrigo Guerra y Nagendra, con el propósito de tocar durante varias horas seguidas a los elementos de la naturaleza y sus espíritus. ${ }^{9}$ La exploración vocal de Paloma parte de la copla o baguala, que estudió con Miriam García, discípula a su vez de Leda Valladares. En una entrevista en 2012 identifica sus conceptos estéticos con artistas que ya venían generando electrofolclore, grabando sonidos de la naturaleza y de instrumentos autóctonos y procesándolos digitalmente, como Tonolec, Gaby Kerpel o Zizek. ${ }^{10}$ En 2015 se difundió su segundo trabajo discográfico, Para bien, con una imagen animada del rostro de la artista como portada, de cuya frente se proyecta una luz o rayo [ver imagen 3].

La plataforma de difusión musical Last.fm define la experiencia de Paloma del Cerro como "El trayecto de encontrarse a sí misma en el canto”: “'La música es un medio de transformación muy fuerte, al cantar se rompe una estructura y se conecta con el corazón', afirma la artista, que al día de hoy además de tomar clases de canto, las dicta y lleva adelante su propio taller." ${ }^{11}$

En enero de 2017 el grupo realizó una presentación en La Cúpula del Centro Cultural Kirchner. Allí se la puede ver desplegando una performance, cantando con todo el cuerpo, encarnando un personaje. Es la única artista mujer sobre el escenario, junto a otros tres músicos. Pero la escena visual es ella; no interactúa con ellos que están en un plano retirado. Paloma se concentra en ella misma. Acompaña el canto con movimientos expresivos, con vestuarios diseñados especialmente que a menudo remiten a animales, como plumas o pieles artificiales [ver imagen 4]. También incorpora algunos elementos artesanales típicos de las culturas étnicas de Argentina, como los pompones de algodón del altiplano, o los adornos de plata mapuches, pero desmarcados de una referencia cultural concreta. De la misma manera combina instrumentos tradicionales como el birimbao, el charango, un tambor turco, entre otros.

Una de las canciones del primer disco es "Curandera". Allí se puede encontrar una síntesis de su propuesta musical y performática;

$$
\begin{aligned}
& \text { Curando, curandera, curando } \\
& \text { sacando, toda maleza } \\
& \text { Curando, curandera, curando }
\end{aligned}
$$

\footnotetext{
7 Zimerman, Gaspar. 17/01/2012. "Paloma Kippes: Superficies de placer". Diario Clarín, https://www. clarin.com/fama/paloma-kippes 0 SkKUoI 3vXl.html

8 20/05/2017: https://diariohoy.net/espectaculos/paloma-del-cerro-soltar-tiene-recompensa-95942

9 Algunas de las canciones que produjo el conjunto se pueden escuchar en Youtube, como la siguiente: "Marimba" https://www.youtube.com/watch?v=xCmHpAQ5JIU

10 Zimerman, Gaspar. 17/01/2012. "Paloma Kippes: Superficies de placer". Diario Clarín, https://www. clarin.com/fama/paloma-kippes 0 SkKUoI 3vXI.html

11 https://www.last.fm/es/music/Paloma+del+Cerro/+wiki
} 
sacando toda, impureza.

Agradecemos a la madre tierra

por todo lo que ella nos da

sacando toda impureza.

En el video de esta canción, Paloma Kippes es una mujer-pájaro que se le aparece a una niña en el bosque. ${ }^{12}$ Al cantar este tema por momentos realiza efectos de segmentación de un mismo sonido como si estuvieran procesados digitalmente pero de modo mecánico; es decir que su canto no tiene una apariencia tradicional y los sonidos que la rodean tampoco. La temática y el audiovisual conectan con el universo popular y rural pero a través de una sonoridad contemporánea. Incluso, una estrofa intermedia de la canción está interpretada en clave de rap por Paz Ferreyra como invitada.

El tema de la curación está muy presente en su trabajo; "Para mí la música es medicina pura". ${ }^{13}$ Su segundo disco, Para bien, está realizado junto a Gerardo Morel, Ezequiel Luka, Migma y Lucas Penayo: "El disco está planteado como una celebración, una ceremonia, un viaje."14 Una de las canciones es "Para todas las mamitas del mundo", que toma la melodía y frase inicial de una canción tradicional, "Reloj de campana", que Paloma conoció a través de una chamana mexicana. ${ }^{15}$ En esta canción convergen instrumentos de percusión tradicionales (djembe, congas, timbal y bombo), con guitarra eléctrica, scratches en vinilos, teclado y acordeón. La modificación de la letra se orienta directamente a reivindicar poderes femeninos sagrados:

$$
\begin{aligned}
& \text { Reloj de campana tócame las horas } \\
& \text { para que despierten las mujeres todas } \\
& \text { porque si despiertan todas las mujeres } \\
& \text { irán recobrando sus grandes poderes. }{ }^{16}
\end{aligned}
$$

El audiovisual representa la canción a través de un ritual en el que intervienen fuerzas femeninas no humanas que colaboran en el despertar de la propia Paloma. Esta canción continúa enfatizando la hibridación de las referencias espirituales. Como en el anterior, la naturaleza es protagonista: la luna, las piedras, los cuatro elementos (agua, tierra, fuego y aire). En esta canción, así como el video, también aparece Paz Ferreyra pero en vez de personificar a Miss Bolivia en este caso representa una diosa hindú que guía parte del ritual del despertar. Respecto a esta canción del disco, Paloma Kippes dice lo siguiente;

\begin{abstract}
El despertar femenino tiene que ver con un momento que vivimos, que no tiene que ver solamente con la mujer, sino con lo sutil, con la escucha. No es sólo de la mujer la tarea, se trata de equilibrar esa energía masculina y femenina que todos tenemos dentro. (...) La idea tiene que ver con ablandar esa dureza, equilibrar y hermanarnos. La madre naturaleza es fraternal, y somos parte de eso, sólo que vivimos en un sistema que nos lleva a olvidar esa conexión en la que todo está entrelazado. Ahí vienen las cadenas, "una mentira produce mil mentiras", dice la frase. Uno elige todo el tiempo, no existe no elegir, lo hacemos desde que nos levantamos hasta que nos acostamos. Hay que arrancar por uno, porque vamos atrayendo. Es magnetismo puro. ${ }^{17}$
\end{abstract}

Durante el año 2018 Paloma Kippes pasó buena parte del tiempo fuera de la Argentina, mayormente en la costa de México. Venía participando hacía un tiempo en diversos festivales en la Riviera

\footnotetext{
12 Videoclip de "Curandera": https://www.youtube.com/watch?v=j4KHvziuVms

13 https://www.clarin.com/musica/paloma del cerro-para bien 0 Bkq0GttPXx.htm [20/05/2015]

14 https://www.clarin.com/musica/paloma del cerro-para bien 0 Bkq0GttPXx.htm [20/05/2015]

15 En entrevistas la artista sostiene que Reloj de campana es una canción popular mexicana, pero también hay referencias de la canción como huayno peruano.

16 Una de sus versiones tradicionales, hay muchas, es la siguiente: Reloj de campana/cadenita de oro/ tocame las horas/ para retirarme.

17 https://www.clarin.com/musica/paloma del cerro-para bien 0 Bkq0GttPXx.htm [20/05/2015]
} 
Maya, ámbito donde se realizan encuentros internacionales de mujeres en torno a las prácticas espirituales de los que han participado otras artistas argentinas. ${ }^{18}$ A fin del año 2018 se estableció en dicho país.

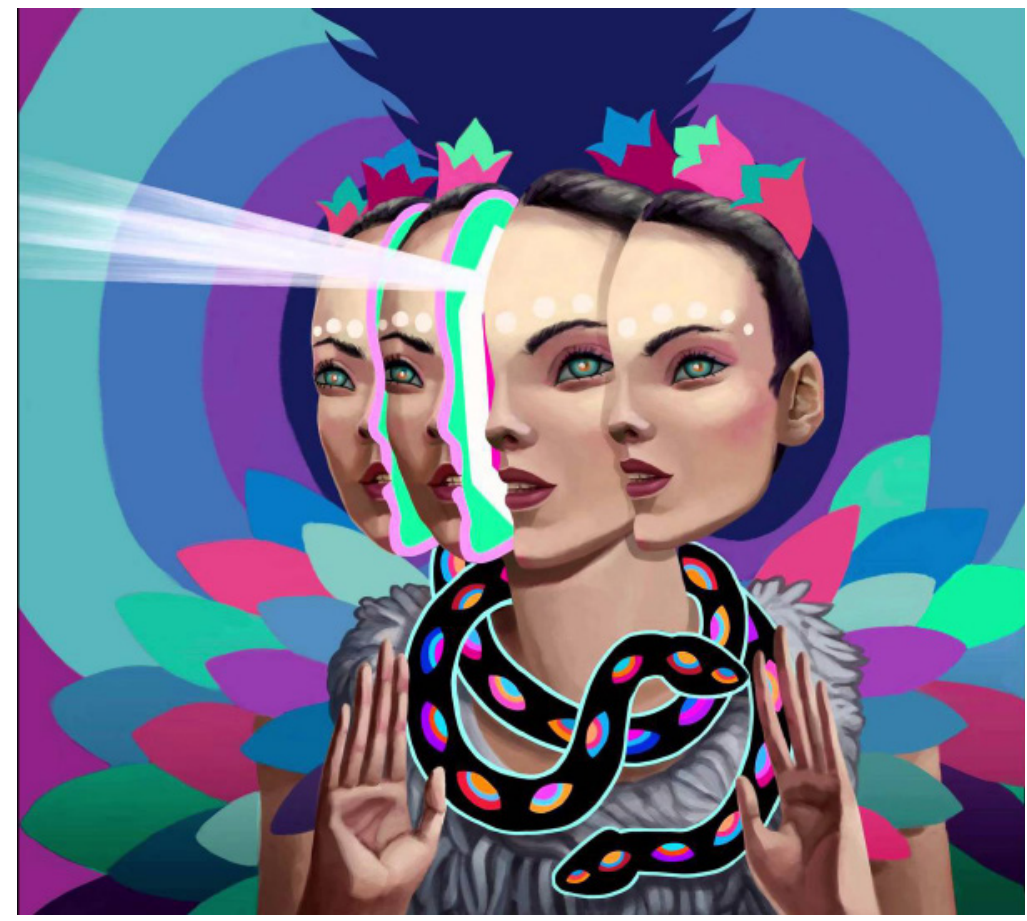

Imagen 3. Arte de tapa del segundo trabajo discográfico, Para bien (2015).

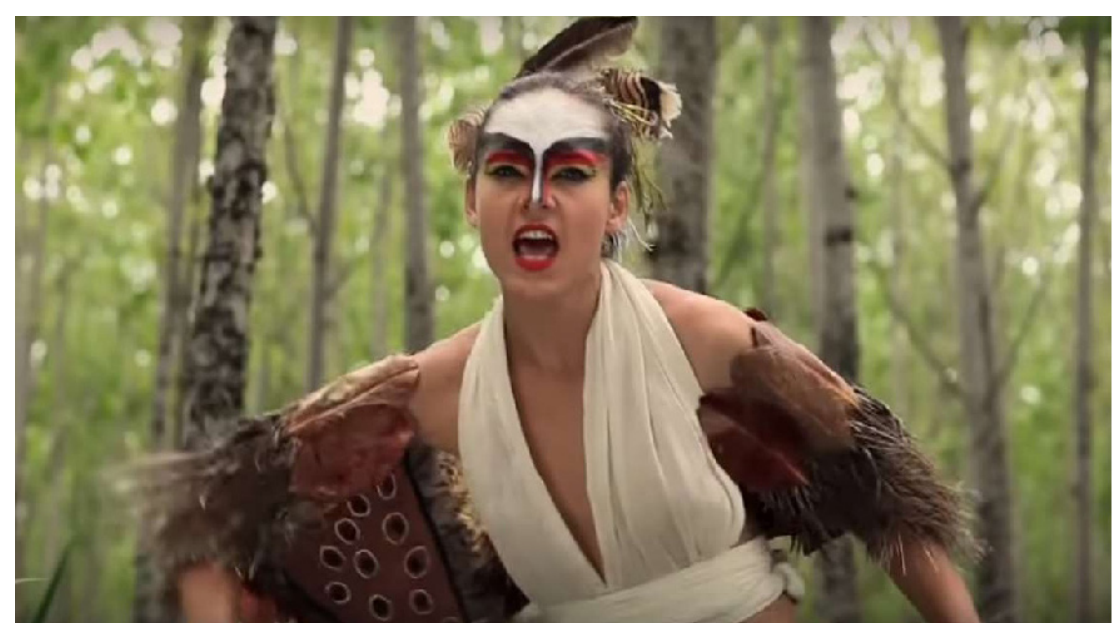

Imagen 4. Screenshot del videoclip del tema "Curandera".

\section{Perotá Chingó}

Perotá Chingó es un dúo integrado por Julia Ortiz y Dolores Aguirre que comenzó en 2011, después de un viaje por la costa uruguaya. Se costeaban los gastos de la estadía haciendo música a la gorra; no habían pensado en un proyecto profesional con la música. En Cabo Polonio conocieron a un director de cine, Pocho Álvarez, que realizaba el seguimiento de una banda de rock, Alerta Pachuca. Ese mismo día

18 Los encuentros de los que participó Paloma del Cerro en Playa del Carmen están organizados por Mujer Raíz (https://www.mujerraiz.com.mx/inicio/). 
Álvarez las filma interpretando una canción de Dolores Aguirre, "Ríe Chinito", y meses después comparte el registro en Youtube, que se viraliza hasta llegar a más de las 20 millones de visitas que tiene actualmente. ${ }^{19}$ El video comenzó a ser visto y compartido por personas de distintos lugares de Latinoamérica, sobre todo de Argentina y de Chile, mediante posteos preguntando por "la banda"20: "Pasaron un montón de cosas misteriosas y que son lindas que no tengan explicación. Las personas que lo vieron por primera vez no entendían qué era lo que los atrapaba tanto. Algo las absorbió", relata (Julia Ortiz en Plaza, 25/5/2018). ${ }^{21}$

Esta génesis inesperada fundó una atmósfera particular que el dúo recogió y sostuvo a través de su propuesta artística. En diciembre del 2011 se forma Perotá Chingó, incorporando a Martín Dacosta en la percusión y Diego Cotelo en la guitarra. Hasta ahora Ya cuentan con tres discos: Un viajecito (2012), Perotá Chingó (2013) y Aguas (2017). En los dos primeros, abordaron algunos temas propios pero se hicieron conocidas sobre todo sus versiones de canciones de diversos géneros musicales de artistas de Argentina, Uruguay y Brasil. Actualmente, realizan giras a esos países además de Colombia, Chile, México o España, llenando espacios como el Circo Voador en Río de Janeiro. Como ocurre con Paloma del Cerro y Miss Bolivia, su público está compuesto mayoritariamente de mujeres, cuestión que se repite en los países en los que se presentan.

El discurso espiritual de Perotá Chingó fue progresivo. El disco Aguas marcó un punto de consolidación de su propuesta musical y un énfasis en lo espiritual. El arte visual del disco tiene un mandala para cada una de las canciones: "Es un disco mucho más personal, todas las canciones y letras son cosas que realmente nos han pasado, cosas que hemos transitado y que a través de la música las expresamos (...) Es más de adentro, más real." (Julia Ortiz en Leigthon 5/12/17). ${ }^{22}$

La presentación de su página en Facebook dice lo siguiente:

\begin{abstract}
Perotá Chingó es el estrecho vínculo entre tensión y armonía de dos poderosas voces y el prodigio resultante de esa unión; así también la relación entre seres que excede lo concretamente musical. A primera vista, Perotá es movimiento, es el viaje, el amor por nuestra tierra y sus paisajes, el intercambio cultural y la integración de lo distinto; y todo eso se refleja fielmente en los primeros discos y años de su carrera donde aparece esa música fresca y descontracturada, de cara al viento, absuelta de géneros y desentendida de formas, poco pretenciosa desde la complejidad, pero capaz de hacer resonar algunas fibras internas y profundas de quien se entregue a escucharlos. ${ }^{23}$
\end{abstract}

En la serie de imágenes de promoción de Aguas utilizadas para difusión de los recitales de presentación se puede ver a las artistas en un paisaje desértico, envueltas en telas livianas que recubren sus cabezas y parte del rostro [ver imagen 5].

En Perotá Chingó lo espiritual es orgánico. Aires de folclore argentino y latinoamericano con una vuelta estilística novedosa, las canciones no presentan ideas definidas o cerradas, son breves y de frases sueltas, con estrofas muy distintas entre sí.

A mediados del 2018 ofrecieron varias fechas de recitales en el Teatro ND Ateneo de Buenos Aires. Durante la primera parte del recital cantaron la mayoría de las canciones de Aguas de corrido prácticamente sin interrupciones entre un tema y otro. Entre ceremonia y recital, la propuesta del vivo sostenía el mismo clima del álbum, de contrastes que se mantienen en un rango de volumen bastante homogéneo que va enlazando los temas [ver imagen 6].

\footnotetext{
19 https://www.youtube.com/watch?v= aIuna5a8Dc

20 en Ramos, Diana, 22/09/2014: http://revistamito.com/entrevista-perota-chingo/

${ }^{21}$ https://www.lanacion.com.ar/2137630-perota-chingo-un-veranoun-videouna-cancion-y-un-fenomeno-musical

22 https://www.nuevamujer.com/entretenimiento/2017/12/05/juli-de-perota-chingo-lo-nuestro-fue-una-cuestion-de-sincronia.html

23 https://www.facebook.com/perotachingo/ [Fecha de consulta: 18/01/2019].
} 
El día anterior al recital había ocurrido un eclipse. Uno de los pocos comentarios entre canciones fue de Julia Ortíz refiriendo al cambio energético del evento interpretado en clave astrológica: “¿Cómo se sintieron ayer? Qué fuerte ¿no?".

"Toda vida" es una de las canciones de Aguas;

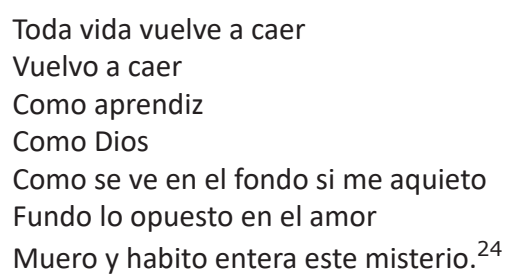

Antes de interpretarla en el recital, Dolores Aguirre, la autora de la canción, dijo que se trataba de un tema muy especial para ella vinculado a un momento particular de su vida. La letra expresa en buena medida el carácter emocional del tema, pero el estilo vocal de las segundas voces enfatiza la dimensión estético-religiosa de la canción, recreando cierta versión de coro celestial. Uno de los momentos más intensos del recital fue durante la interpretación de "Reverdecer", una canción la que Perotá Chingó vuelve a ser sólo un dúo cantando a capella;

\author{
Fuerza natural, fuerza \\ No me falte al aire \\ para atravesar tormenta \\ cuando el trabajo sea reverdecer. \\ Y si me apuna el viento \\ No me falte el aire \\ Vuélvome a las alturas \\ Cuando el trabajo sea reverdecer. \\ (...) \\ Para avivar el fuego \\ No me falte el aire \\ Mi voz sea la herramienta \\ Cuando el trabajo sea reverdecer.
}

En el recital cantaron la canción casi a oscuras, formando un círculo con sus movimientos, cantando y bailando. En septiembre de 2018 se publicó un audiovisual de "Reverdecer" que recupera la performance del tema en el recital. ${ }^{25}$

Asimismo, Julia y Dolores transmiten una unión muy fuerte entre ellas que ha llevado pensar que conformaban una pareja afectiva, y cuentan que en determinado momento dejaron liberada esa ambigüedad de parte del público. ${ }^{26}$ Justamente, interesa ver lo que Perotá Chingó simboliza en términos de complicidad y de hacer música entre mujeres. Por otro lado, en otra entrevista Julia Ortiz se distancia del feminismo:

\begin{abstract}
"Yo no soy feminista, ni machista", porque me pasa un poco eso con todo. No soy de extremar nada, o sea no me voy a ningún extremo. Porque no es mi forma de expresarme, estoy completamente a favor de que cada uno encuentre su forma de expresarse y que si hay alguien que realmente siente el feminismo como su bandera me parece alucinante, no es mi forma de expresarme. Si me he dado cuenta que en las canciones, en los mensajes que damos, en la forma que tenemos de hablar a las feministas les gusta, se sienten identificadas. Pero no es mi bandera en particular. Con respecto a lo que es el despertar de la mujer yo estoy viendo que las mujeres están tomando una fuerza que es la que han tenido siempre. No es que ahora les está
\end{abstract}

\footnotetext{
24 "Toda vida": https://www.youtube.com/watch?v=CSvx2P -fPc

25 https://www.youtube.com/watch? $v=C S v x 2 P-f P C$

26 https://www.clarin.com/espectaculos/musica/perota-chingo-chicas-pasaron-youtubers-hippies-girar-mundo-canciones_0_S1K_wiagQ.html
} 
apareciendo. La mujer desde que puede parir, desde que tiene un cuerpo y puede tener un bebé es porque tiene una fuerza infinita. $O$ sea es algo que es enorme. Entonces, lo que yo siento es que la mujer está empezando a valorar esa fuerza y entender que está buenísima". ${ }^{27}$

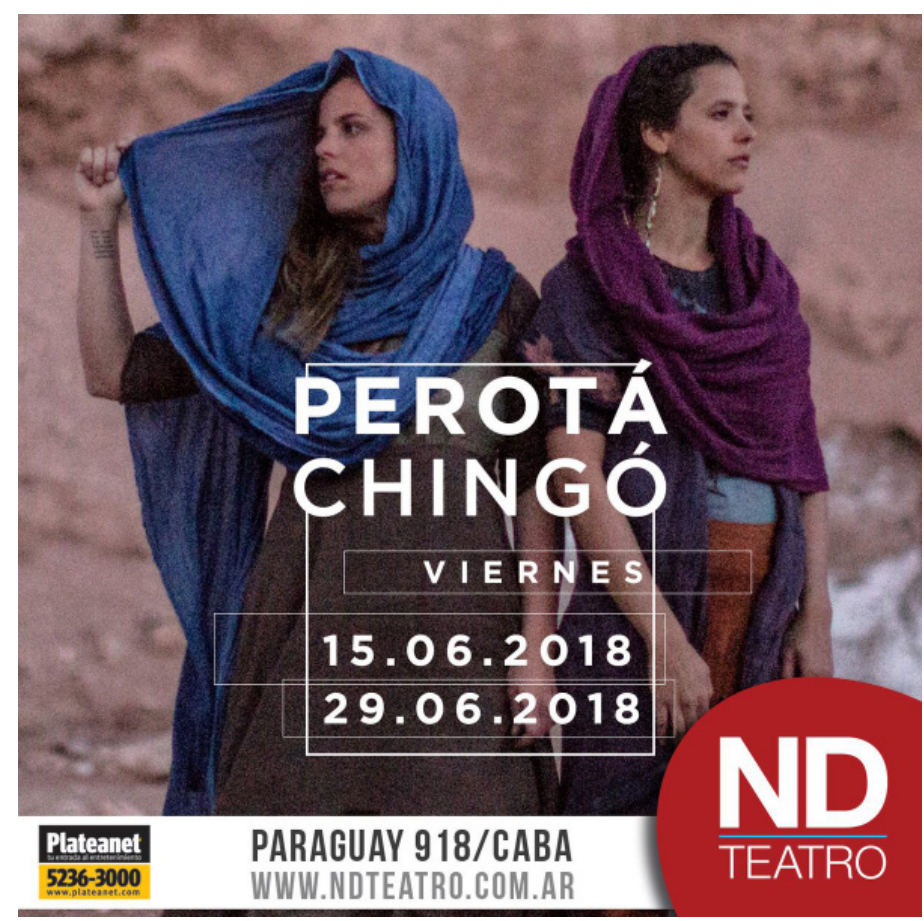

Imagen 5. El dúo de Julia Ortiz y Dolores Aguirre en las visuales que utilizaron para presentar el disco Aguas en 2017.

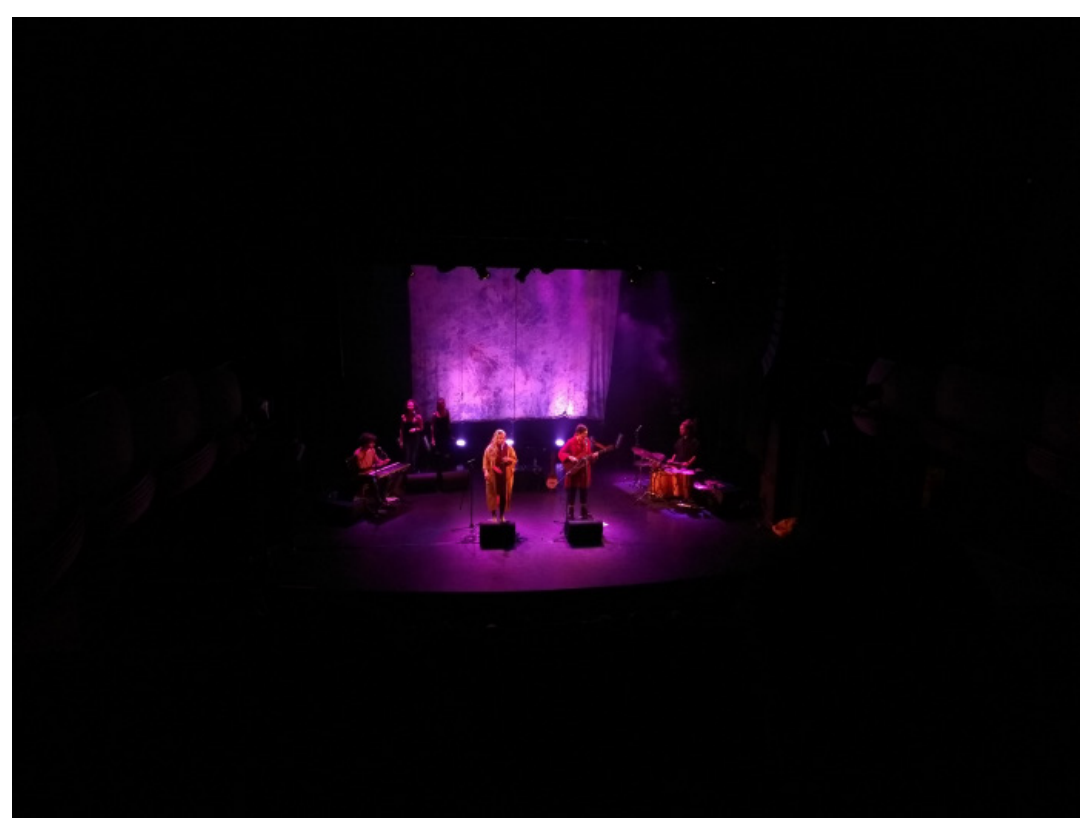

Imagen 6. Recital de Perotá Chingó en el ND Ateneo, julio de 2018. Foto del autor.

27 https://www.nuevamujer.com/entretenimiento/2017/12/05/juli-de-perota-chingo-lo-nuestro-fue-una-cuestion-de-sincronia.html 


\title{
La Yegros
}

Resta el último ejemplo. La descripción de este trabajo musical va a ser más acotada porque hay elementos que se reiteran y que por lo tanto no es necesario reponer. No obstante, también tiene sus particularidades, estéticas y culturales: su inclusión es enriquecedora porque da cuenta de la inserción de estos trabajos en un circuito artístico internacional.

Mariana Yegros es conocida en el mundo musical como La Yegros. Es cantante y compositora y realiza música electrónica mixturada con ritmos latinoamericanos, destacando la combinación de géneros populares latinoamericanos, como la cumbia y el huayno, y del repertorio folclórico argentino más específico, como el chamamé. Este género característico de las provincias de la región Mesopotamia de Argentina se asocia con la historia familiar de la cantante. Mariana Yegros nació en Buenos Aires pero su madre y su padre son de la provincia de Misiones. Ella cuenta que en su casa la música que se escuchaba era cumbia y chamamé, cuestión que fundamenta sus elecciones estéticas. ${ }^{28}$ Comenzó a estudiar en el Conservatorio de Morón, pero al poco tiempo quedó seleccionada para cantar en la compañía de danza-teatro denominada De La Guarda, que se había formado en 1994. En su momento, De la Guarda provocó una repercusión en el ámbito artístico de Buenos Aires, entre otras cosas, por crear espectáculos sofisticados en el uso de tecnologías y a la vez vincularlo con rasgos de la cultura popular argentina. Justamente, sobre esta matriz creativa se va a desarrollar la carrera solista de Mariana Yegros;

\begin{abstract}
Nosotros ya éramos conocidos en el underground de Buenos Aires. Underground pero a la vez en un sistema donde a la vez la música nuestra era innovadora. Gente que estaba más en contacto con lo nuevo era nuestro público, también muchos extranjeros que iban a las fiestas Zizek, que les gustaba escuchar algo diferente. Nosotros pertenecemos a eso, y éramos respetados en ese lugar. ${ }^{29}$
\end{abstract}

Pero La Yegros se hace muy conocida primero en Francia, a raíz del éxito en radios de público masivo con la canción "Viene de Mí" que da nombre a su primer álbum, de 2013. Desde 2015 vive en ese país, y sigue asociándose con músicos argentinos tanto para la interpretación como para la producción de sus discos. Es el caso de Gabriel Kerpel -King Coya- que participó en sus dos trabajos discográficos. Kerpel había sido el director musical de los espectáculos de De La Guarda y de Fuerza Bruta después, un punto de conexión con Paloma de Cerro, que menciona a este mismo músico como uno de los referentes de su búsqueda artística. Después de un crecimiento profesional que se fue expandiendo por Europa, La Yegros vuelve a la Argentina para participar en festivales internacionales, como Lollapalooza edición 2017. A raíz de esta participación, la nota periodística de un importante medio local titula lo siguiente: "La argentina que hace bailar al mundo"30.

Con aires de chamamé, una de las canciones del primer disco se llama "Trocitos de Madera", compuesta por Yegros y Kerpel. El sonido del acordeón sitúa a la canción en el contexto de la provincia de Misiones. La letra habla de una niña que llora trocitos de madera, es dramática. El videoclip de la canción sugiere cuestiones sobre la depredación de la selva de la provincia, como los sonidos digitales de la introducción representando los golpes de un hacha talando un árbol. ${ }^{31} \mathrm{El}$ mensaje es ecológico pero no sólo porque nuevamente lo que aparece es una naturaleza animada, además de imágenes de un altar de la niña, o el fluido verde que emana mágicamente del hombre que representa al empresario

\footnotetext{
28 Entrevista en Radio Francia. Fecha de publicación en Youtube: 7/04/2016.https://www.youtube.com/ watch? $v=Y f 2 X 1 a 4 z 5 I Y$

29 Entrevista en Radio Francia. Fecha de publicación en Youtube: 7/04/2016.https://www.youtube.com/ watch? $\mathrm{V}=\mathrm{Yf} 2 \mathrm{X} 1 \mathrm{a} 4 \mathrm{z} 5 \mathrm{IY}$

30 Carlos Iogna Prat, 17/02/2017

https://tn.com.ar/musica/hoy/la-yegros-la-argentina-que-hace-bailar-al-mundo 773315
}

31 Videoclip de "Trocitos de madera": https://www.youtube.com/watch?v=ZRsHUCK-Yno 
depredador como castigo divino hacia el final del audiovisual. En el medio, se intercalan imágenes de La Yegros cantando con la banda, en una escena en la que ella aparece como si dirigiera la celebración de un ritual [ver imagen 7]. En una entrevista la artista cuenta que para las presentaciones en vivo ella misma decora los escenarios, con telas y otros objetos recreando la selva misionera.

En este disco hay otra canción que se titula "El bendito";

$$
\begin{aligned}
& \text { Bendita la noche bendito el frío } \\
& \text { bendita virgencita de los fugitivos } \\
& \text { benditos los diablos del Paraná } \\
& \text { bendita la niebla, bendito el yerbal. }{ }^{32}
\end{aligned}
$$

En esta canción el chamamé aparece como una música bendita, y menciona un conjunto heterogéneo de creencias, sobre todo asociadas a cultos católicos, pero también a las prácticas religiosas de los guaraníes que habitan esta zona del país, lindante con Brasil y Paraguay. A su vez, "El bendito" es una de los temas del videojuego FIFA World Cup de 2014. En 2016 se editó su segundo álbum cuyo nombre es Magnetismo. Según la artista refiere a la energía de atracción del público con la banda, y a principios de 2019 La Yegros anunció la edición del tercer trabajo titulado Soltar.

En la entrevista a Mariana Yegros ya mencionada, el periodista Jordi Batallé comenta que no es habitual ver a una mujer liderando conjuntos de música latina, y ella responde: "poco a poco vamos tomando la batuta".

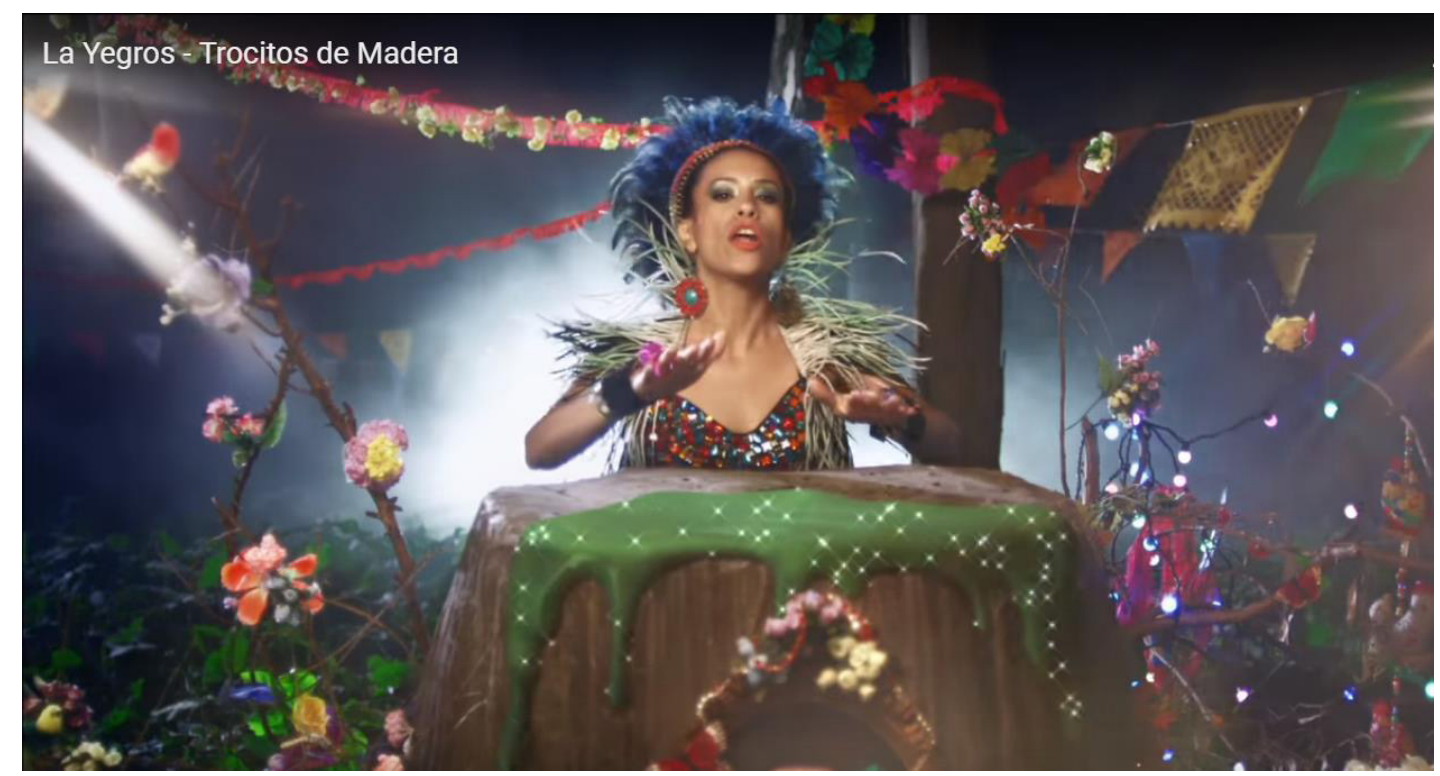

Imagen 7. Screenshot del videoclip de la canción "Trocitos de madera", publicado en enero de 2014.

\section{Genealogía de lo espiritual en las experiencias musicales de mujeres}

A partir de estas descripciones emergen inicialmente dos interrogantes; por un lado, si se puede identificar cuándo empiezan a aparecer referencias de las espiritualidades contemporáneas en la música popular argentina, y por otro, qué podemos encontrar en la historia respecto de la dimensión religiosa asociada específicamente a la actividad musical de mujeres.

En los trabajos socioantropológicos la primeras consideraciones de nuevas espiritualidades en la música popular argentina pueden encontrarse en la escena electrónica bailable o dance que emerge durante la década del 1990, asociado a los preceptos de autoconocimiento y autonomía de la Nueva Era, vinculado también con

32 Audio de "El bendito": https://www.youtube.com/watch?v=5AnuawYM9mg 
la percepción de los efectos de las drogas de diseño (Gallo y Semán 2010; Lenarduzzi 2012). A su vez, estos modos de concebir y disfrutar la experiencia musical estaban en relación con la des-heteronormativización de algunas prácticas de baile. A principios del 2000, también aparecía en un ambiente más insospechado como es el baile del tango y el universo de las milongas de Buenos Aires. Nociones de energía y de autonomía relativa dentro de los códigos coreográficos tomaron protagonismo en un estilo de baile, el tango nuevo, de la mano de una generación joven de bailarines y bailarinas profesionales y amateurs, coincidente con la flexibilización de la heteronorma cuyo exponente más evidente es el tango queer (Liska, 2018). ${ }^{33}$

En la historia artística reciente de la música popular argentina la cantante Charo Bogarín, con el dúo Tonolec, fue pionera en incursionar en el folk-electrónico desde una puesta performática o multidimensional, buceando en los cantos y otras tradiciones musicales del pueblo qom-toba, y guaraní después. ${ }^{34}$ Su consolidación artística, que comenzó alrededor del 2005, fue de la mano de una propuesta musical desarrollada en términos visuales con diseños de vestuario novedosos y marcando, sobre todo, la figura de Bogarín como una mujer nativa de fuerte personalidad. Actualmente Bogarín combina su presencia constante en recitales y festivales con otro tipo de actividades musicales, tales como la dirección de encuentros grupales para la exploración del canto a partir de la transmisión de su conocimiento sobre las culturas musicales y las cosmovisiones de pueblos originarios del territorio argentino. Se pueden señalar experiencias anteriores de proyectos musicales vinculados a los cantos sagrados de la cultura mapuche, los tayül relacionados con la actividad de las machis o chamanas mapuches, como el caso de Aimé Painé en la década de 1980 y Beatriz Pichi Malem de los 90’ en adelante. En este sentido podemos pensar la figura de Bogarín como una artista que articuló mundos musicales hasta entonces disociados: el canto tradicional en lenguas indígenas con el universo de la electrónica, solo que no invocaba fuerzas no humanas o señalaba el origen sagrado de las canciones originales. ${ }^{35}$ Leda Valladares, María Elena Wash, Luisa Calcumil, Miriam García, Silvia Barrios, Graciela Mendoza, Anahí Mariluán son, cronológicamente varias de las cantantes que llevaron a los escenarios los cantos tradicionales de las culturas originarias del territorio argentino. En su mayoría han sido mujeres las dedicadas a estos repertorios, una tradición dentro de la tradición.

Otro antecedente de artistas de una apuesta performática en los escenarios asociado a imágenes de religiosidad popular es la cantante mexicana Lila Downs, cuya visibilidad en la Argentina fue creciendo tras sus visitas constantes al país, logrando formar un público local al punto de que durante el verano de 2019 dio un importante recital público en Buenos Aires, organizado por el estado. Asimismo, la repercusión en Argentina del grupo colombiano Bomba Estéreo identificado con el nombre de tropipop, cuya cantante Liliana Saumet difunde una profusa colección de imágenes rituales en el contexto de la selva donde vive, el Parque Nacional Tayrona. Comunicación y cuidado ecológico de la naturaleza son aspectos que van apareciendo una y otra vez en lo musical connotado con lo femenino.

\footnotetext{
33 En la investigación musical de perspectiva sociológica en América Latina no encontramos trabajos que aborden la temática religiosa, salvo caracterizaciones de ciertos recitales de rock como rituales contemporáneos. Durante el siglo XX, la musicología sí se dedicó a analizar la música religiosa pero predominantemente de tradición católica, mientras que desde la década del $60^{\prime}$ en adelante, la etnomusicología desarrolló innumerables trabajos sobre rituales, prácticas de chamánicas de curación e instrumentos musicales sagrados en diferentes etnias y comunidades de la región. Sin embargo, aunque aislados hay algunos indicios de interés en estos temas; en 2018 se publicó en México una compilación de trabajos reunidos en el libro la música y los mitos sobre México y Brasil, cuyos editores provienen de letras y comunicación. Esta parece la influencia de las propuestas decoloniales (y sus vertientes) y de ciertos desplazamiento de los temas e intereses de investigación musical en países de América Latina. En este libro aparece un trabajo titulado "Das epistemologías feministas decoloniais ao sagrado feminino em música no Brasil" de Laila Andresa Cavalcante Rosa que recoge desde lo académico, la valoración de lo espiritual como fuente de poder de lo femenino, alineado con las representaciones musicales. Se puede mencionar también que en 2017 la Asociación Iberoamericana de Etnomusicología (SIbE) realizó un primer encuentro dedicado a la temática: "Losing my Religion. Espiritualidad, religión y música popular" (Santander, 15-17 de diciembre).

34 Qom-toba y guaraní son distintas etnias de la Argentina.

35 En realidad Beatriz Pichi Malem en su disco Plata del año 2000 ya exploraba los recursos electrónicos, pero con mucha menor resonancia y divulgación.
} 
Los trabajos de música y género pioneros de Susan McClary (1991) y Lucy Green (1997), que actualmente son referencias clásicas del área, hablan de la postergación histórica de las mujeres en la actividad musical. A la vez destacan que, en espacios puntuales de la actividad, generalmente consideradas de un rango menor, las mujeres tuvieron una participación mayor, justamente. Una es el canto; la voz es el instrumento "natural" por antonomasia. En el otro extremo se encuentra el desempeño de actividades musicales asociadas a tecnologías aplicadas a la producción de sonido, desde la música electroacústica a la composición digital en todas sus variantes.

En los ejemplos presentados y analizados esta división de roles se mantiene: las músicas cantan y a veces componen; los músicos ejecutan instrumentos convencionales, digitales y producen los discos. El cambio que ofrecen estas propuestas tiene que ver con los sentidos espirituales de, o a través de, la música. Pero el fenómeno emergente de nuevas espiritualidades relacionadas con la creación musical no se restringe a las artistas mujeres. En Argentina, una de las bandas de rock actualmente más exitosas se denomina Los Espíritus. Produjo su primer disco en 2013. En su último disco, Agua Ardiente (2017) la canción, "Perdida en el fuego" dice lo siguiente:

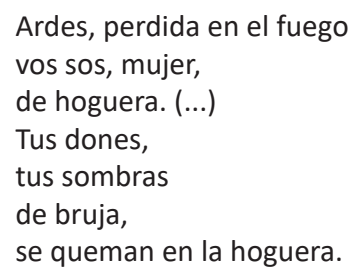

Nicola Cruz es un músico ecuatoriano que durante el año 2018 obtuvo un reconocimiento internacional exponencial, junto a Chancha vía circuito con propuestas parecidas. Su trabajo musical está anclado en las tecnologías digitales pero recreando un universo ritual naturalista. Asimismo, ha tenido encuentros con artistas identificadas con las estéticas espirituales del estilo de Paloma del Cerro, como el caso de Huaira. Con ella estrenó el videoclip "Colibria" (2015), que representa la historia de una niña nacida de un volcán. En definitiva, la música popular latinoamericana identificada con nuevas espiritualidades, aun en músicos varones, reitera representaciones de empoderamiento femenino ligadas a lo sagrado.

Música, mujeres y nuevas espiritualidades es una articulación que aparece de modo transversal en producciones de diferentes ámbitos culturales que incluyen la comunicación masiva. El videoclip de Jennifer López de la canción "Anillo" (2018) contiene un conjunto de referencias estético-religiosas y ritualidades en sintonía con los ejemplos que vimos, solo que con algunas torsiones de sentido significativas. El audiovisual muestra escenas de un cónclave femenino multicultural desmarcado de América Latina inmerso en ambientes suntuosos, como recreando la élite gobernante de un matriarcado exótico y autoritario. Reina más que Diosa, Jennifer López se pone intolerante con un hombre que la corteja, que le ofrece casi todo lo que ella necesita, menos el anillo de compromiso. ${ }^{36}$

Por su parte, Diana Eguía Armenteros analizó las performances sagradas de trabajos recientes de Beyoncé, asociadas al incremento de mensajes políticos antirracistas en su música: "Beyoncé abandonó el clásico papel de objeto sexual de las cantantes pop y se ha convertido en una líder del feminismo espiritual. Una corriente que crece en el underground de Estados Unidos y que invoca el concilio

${ }^{36}$ https://www.youtube.com/watch?v=LryQJ25CnKU 
de las mujeres y su empoderamiento." (Eguía Armenteros, 2017, s/p). ${ }^{37}$ Desde que Donald J. Trump se posicionó como líder político, distintas personalidades del espectáculo enfatizaron su oposición al presidente que, entre otras cuestiones, viene construyendo una identidad cristiana de Estados Unidos, un país en el que tradicionalmente convergen diversas religiones. Eguía Armenteros sostiene que el interés de artistas por diferenciarse del gobierno actual tiene que ver con el desarrollo de múltiples formas del feminismo espiritual. Asimismo señala lo siguiente;

\begin{abstract}
El rescate de las formas antiguas del feminismo espiritual lleva un tiempo colándose por la cultura underground, especialmente entre la población hispana de los Estados Unidos, quienes se ven a sí mismas como herederas de la lucha feminista decolonial en un país cada vez más anti-latino, anti-queer y anti-mujer. (...) Raperas y brujas que se empoderan a través de rituales mágicos y sobreviven a su disciplinaria vida de high school.
\end{abstract}

Las representaciones que se ponen en juego en las performances musicales relevadas por Eguía Armenteros describen expresiones muy parecidas a las vistas en las artistas argentinas; la herencia matrilineal ${ }^{38} \mathrm{y}$ el concilio de mujeres, las narrativas sobre deidades o fuerzas de lo tradicional femenino, como la Madre Tierra, o sobre el ejercicio de roles de sacerdotisas, brujas o diosas, y que redefinen conceptos de cuerpo, naturaleza, familia o comunidad. Asimismo, sostiene que las espiritualidades feministas desafían la autosuficiencia patriarcal, la productividad capitalista y el binarismo heteropatriarcal;

\begin{abstract}
Es imposible discutirle a Beyoncé que es la abeja reina (Queen Bey), como se la conoce popularmente, ella controla la cultura norteamericana como nadie, es una mujer empoderada y consciente de las batallas que aún se debe librar contra el racismo heteropatriarcal en los Estados Unidos. (...) En esta coyuntura hay que entender la encarnación en diosa de Beyoncé, quien convirtió una actuación de música pop en un ritual artístico-espiritual de empoderamiento de las mujeres y, especialmente, de las afroamericanas (Eguía Armenteros, idem, s/p). ${ }^{39}$
\end{abstract}

En la cultura de masas hace algunos años que el feminismo espiritual circula en forma de discursos y de prácticas terapéuticas y de ocio. Nicolás Viotti y Karina Felitti analizan estas propuestas tomando como puntapié la visita a Buenos Aires de Mía Astral en 2016, la consejera espiritual venezolana de repercusión en la comunicación de masas latinoamericana que empezó con videos en YouTube producidos de forma casera desde Miami. Combinando astrología, meditación, nutrición ayurveda y espiritualidad judía, Mía Astral ofrece a un público amplio de mujeres herramientas para auto-gestionar la vida, mediante libros de predicciones anuales, posteos en redes sociales, y conferencias en vivo en teatros, como la realizada en la ciudad argentina ante dos mil personas;

\begin{abstract}
Mía habla a las mujeres y vive la astrología como una cruzada para empoderarlas y para que redescubran su fuerza espiritual y su energía femenina. Su cruzada es para que las mujeres entiendan los patrones de conducta que las hacen sufrir y recuperen su amor propio, aprendan a cuidarse mejor y a sobrevivir en un mundo difícil (Viotti y Felitti, 2016: $s / p)$.
\end{abstract}

Viotti y Felitti sostienen que las seguidoras de Mía Astral en muchos casos también se movilizan por demandas políticas, y agregan una cuestión que parece clave; que este camino de autoconocimiento

\footnotetext{
37 El ejemplo central que analiza Eguía Armenteros es la performance de Beyoncé en la entrega de los Grammy edición 2017.

${ }^{38}$ Es interesante lo que dice Eguía Armenteros de que por primera vez se honra el embarazo en la música pop, debido a la serie de imágenes de la artista embarazada.

39 Una apreciación reciente de los componentes religiosos en la música pop puede verse en un trabajo que revisita la obra de Madonna en los 80 ', y que analiza la apropiación de elementos sacros como un recurso de posicionamiento en un circuito musical hegemonizado por la égida masculina (Lins Lima, 2016).
} 
de lenguaje común funciona como código femenino de sociabilidad entre mujeres.

Por otro lado, también se pueden tomar algunos análisis acerca del contexto religioso actual de la Argentina. Alejandro Frigerio refiere a una progresiva desregulación del escenario religioso en el país desde el retorno de la democracia en 1983 hasta el presente por el cual se fueron modificando creencias y prácticas concebidas como religiosidad popular, anteriormente presentes pero de manera incipiente y poco toleradas, que fueron interviniendo poco a poco el monopolio católico de las décadas anteriores (Frigerio 2007). En este sentido, Nicolás Viotti y Maria Eugenia Funes (2015) analizan las articulaciones recientes entre espiritualidad y política en Argentina, en particular, los vínculos entre la coalición partidaria que gobierna actualmente el país con Mauricio Macri como presidente (Propuesta Republicana -PRO-) y la Fundación El Arte de Vivir (EADV) con Ravi Shankar como uno de sus referentes más conocidos;

\begin{abstract}
En Argentina las espiritualidades Nueva Era se han expandido hacia espacios novedosos, inesperados décadas atrás. Esto llama la atención sobre un proceso de desplazamiento que va desde el ámbito de la vida cotidiana hacia nuevos escenarios como la vida económica, la educación y la pedagogía, las producciones estéticas e incluso la política (Viotti y Funes, ídem: s/p).
\end{abstract}

Estos investigadores sostienen que las conexiones entre el PRO y una corriente de la Religiosidad Nueva Era llevaron a que buena parte de la intelectualidad crítica local afirme que el avance de nuevas espiritualidades forma parte del neoliberalismo cultural, del individualismo atomizante que reza que el único cambio posible es el personal. En este sentido, el trabajo sobre Mía Astral también dejaba entrever las preocupaciones o recelos de parte de otros feminismos, de vertientes académicas o activistas, a narrativas de empoderamiento femenino de circulación en la industria cultural. Viotti y Funes explican que EADV es una fundación que abarca un sector del neo-hinduismo de expectativas proselitistas que propone transformar las cúpulas de poder en occidente a partir de la sabiduría espiritual de oriente, y que identificar esta facción, aun siendo la más ambiciosa, como preceptos neoliberales es, no solo simplista sino que implica no estar comprendiendo el escenario político al que se oponen, en cierta medida obturados por el dominio católico que rige el modo de pensar la religión en nuestro país.

Introducido el debate y sus complejidades, ¿Qué podemos decir de los sentidos que vinculan lo musical con el feminismo espiritual?

\title{
Consideraciones finales
}

Este trabajo da cuenta de una relación entre música y cultura a través de la temática espiritual, mediante un conjunto de representaciones estéticas. En las propuestas artísticas de mujeres que fueron analizadas encontramos narrativas espirituales, por un lado, ligadas a recursos de sanación emocional, y por otro, a poderes mágicos detentados mayormente por mujeres. Estos poderes se traman fundamentalmente en la comunicación de las mujeres con el mundo animal y vegetal. Lo que se expresa y cómo se expresa en la música puede diferir entre sí, pero convergen en una densidad común: representar un tipo de poder divino asociado a la naturaleza femenina. Su ubicuidad contribuye a no definir claramente de qué se trata ese poder, en qué reside exactamente. Los cuatro trabajos están realizados por bandas mixtas, sin embargo, tanto prácticas y poderes espirituales están en conexión sólo con lo femenino. Así, las mujeres artistas exploran sus capacidades creativas y espirituales a través de la música. Por otro lado, tres de las músicas dejan entrever algunos cruces sociales y artísticos comunes: Paloma del Cerro, Miss Bolivia y La Yegros.

A su vez, los sentidos que se estrechan entre mujeres y mundo natural nos llevan a la pregunta de la reiteración de lo femenino como una esencia biológica ahora con enfoque positivo. Sin embargo, al no estar anclado en argumentos de racionalidad científica, ¿ ¿s posible pensarlo en esos mismos términos?

La relación entre música y espiritualidad que se establece a través de estos ejemplos permite pensar en sistemas de creencias en formación, en conjuntos de valores, estéticos y culturales en torno 
a la iniciativas sociales actuales de las mujeres. No se puede afirmar que se trata de representaciones generadas de manera autónoma respecto del dominio masculino, pero sí que expresan cierta ampliación de las posibilidades de experimentar creativamente y de confiar en su contribución en el hacer musical desde una posición social con enfoque de género, feminizada.

En el contexto de la mundialización informacional, es constante ver la replicación instantánea de signos culturales muy similares en ámbitos muy diferentes. En las artistas mujeres es notable ver discursos comunes que emergen del corazón de la industria y del circuito de pequeña escala e independiente del circuito comercial. Asimismo, tanto en los ejemplos desarrollados como en otros mencionados a lo largo del trabajo, la idea de lo latino aparece como elemento identificado con las espiritualidades femeninas expresadas en la música, entre cierta reafirmación étnico-racial y la reproducción del exotismo: el naturalismo primitivista de las estéticas musicales periféricas actualizadas por el protagonismo de las mujeres. Las desigualdades sociales y culturales a lo largo de mundo operan también en las apreciaciones y percepciones de la música.

Por otro lado, en distintas actividades políticas y culturales asociadas al movimiento de mujeres recientemente aparecieron referencias espirituales, como por ejemplo en la multitudinaria marcha del 8 de marzo de 2018 en la ciudad de Buenos Aires [ver imagen 8]; en muestras plásticas o históricas, y en otras actividades en centros culturales vinculados al pensamiento de progresista [ver imagen 9].

Seguramente se pueden reponer otras perspectivas de análisis de los trabajos musicales. Entre la resonancia de lo social y la contribución a lo social, la creación musical viene acompañando la visibilización de las opresiones de género. Las condiciones de colectivización y organización de muchas mujeres en torno de esa desigualdad transversal es representada en la música de distintas maneras. La espiritual es una entre otras. Veremos hasta qué punto pueden confluir, como un proceso de cambio cultural capaz de percibirse plural y no desigual, estableciendo nuevas jerarquías estéticas, religiosas y políticas.

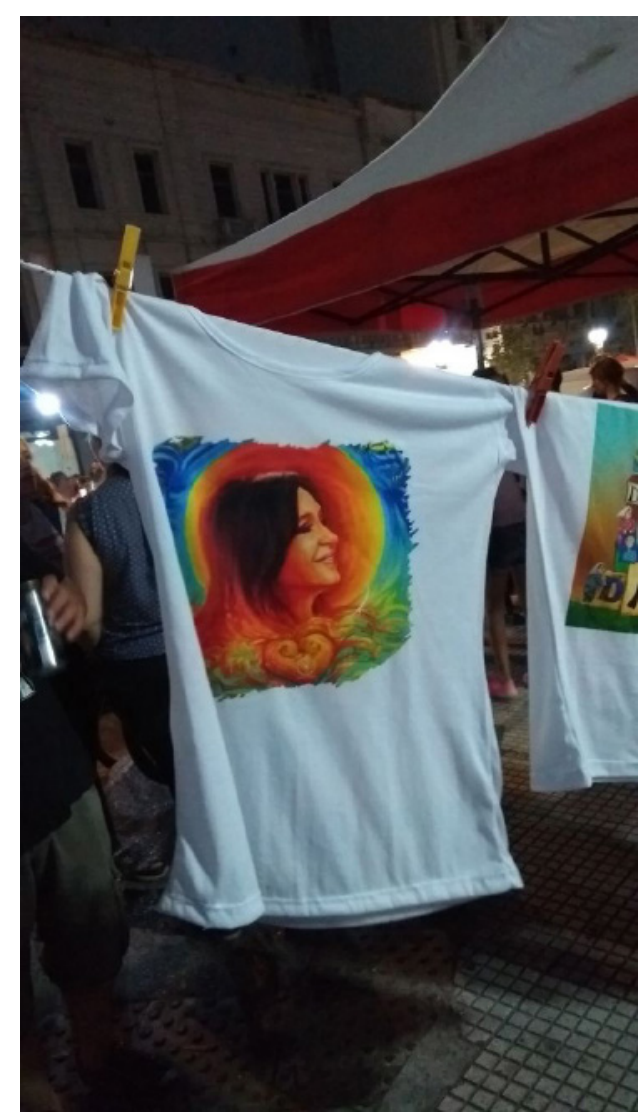

Imagen 8. Estampado con una imagen santificada de la ex presidenta argentina Cristina Fernández. 8 de marzo de 2018. Foto del autor. 


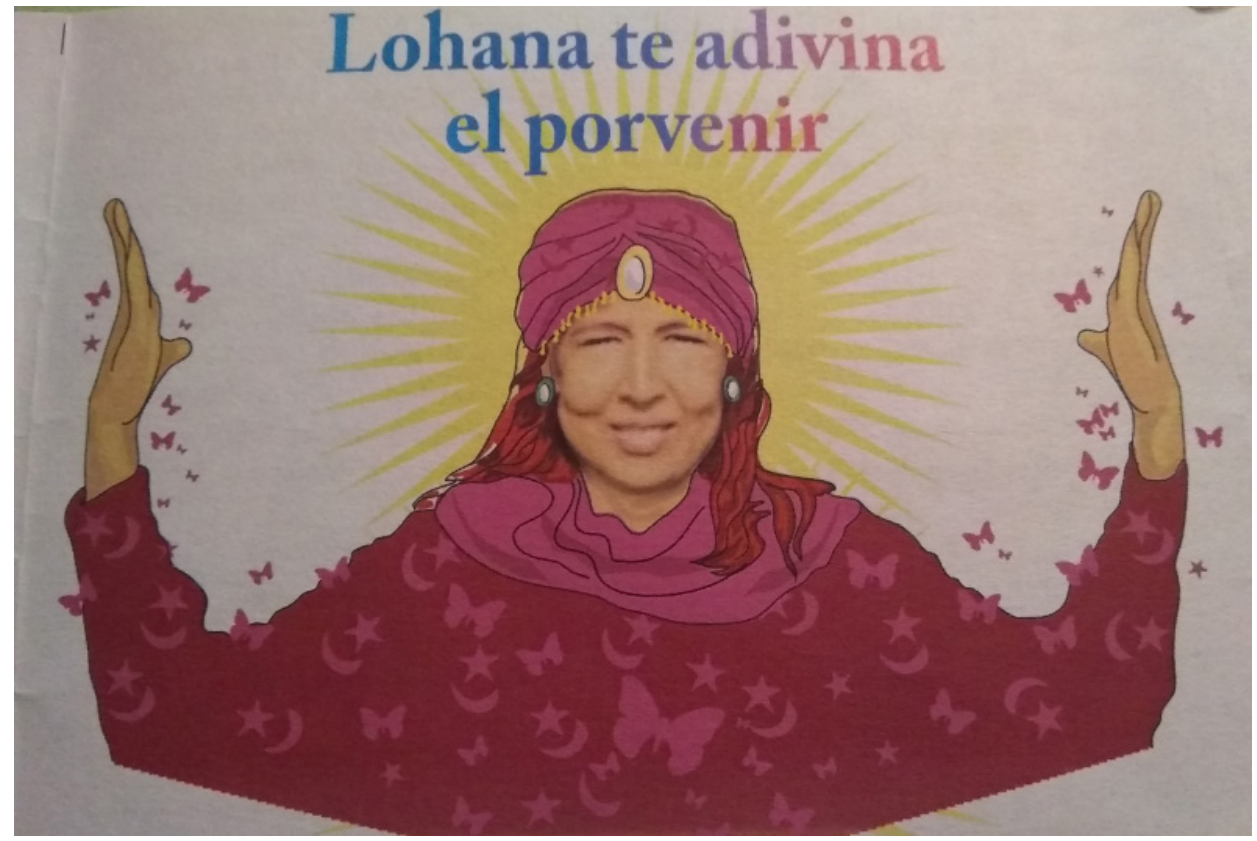

Imagen 9. La dirigente transexual Lohana Berkins, fallecida en 2016, como tarotista. Muestra Células Madre, de María Moreno. Centro Cultural Haroldo Conti, julio de 2018. Foto del autor.

\section{Referencias}

EGUÍA ARMENTEROS, D. (2017). "Beyoncé y el feminismo espiritual”. Revista Anfibia, 4-09-2017.

CAVALCANTE ROSA, L. A. (2018). "Das epistemologías feministas decoloniais ao sagrado feminino em música no Brasil”. En: De la Garza, M. L.; Bonfim, C. (Eds.), La música y los mitos. Investigaciones musicológicas, p.303-326. Tuxtla Gutiérrez: Fray Bartolomé de las casas.

FEDERICI, S. (2015). Calibán y la bruja. Mujeres, cuerpo y acumulación originaria. Buenos Aires: Tinta Limón.

FRIGERIO, A. (2007). "Repensando el monopolio religioso del catolicismo e $n$ Argentina". En: Carozzi, M. J.; Ceriani, C. (Eds.), Ciencias sociales y religión en América Latina: Perspectivas en debate, p. 87-118. Buenos Aires: Biblos/ ACSRM.

FRITH, S. (2014). Ritos de la interpretación. Buenos Aires: Paidós.

GALLO, G.; SEMÁN, P. (2009). "Superficies de Placer: sexo, religión y música electrónica en los pliegues de la transición 1990-2010". Cuestiones de Sociología (5-6).

GREEN, L. (2001). Música, género y educación. Madrid, Morata.

HALL, S. (1984). “Notas sobre la deconstrucción de lo popular". En: Samuels, R. (Ed.), Historia popular y teoría socialista, p.94-112. Barcelona: Crítica.

HOLLOWS, J. (2000). "Feminismo, estudios culturales y cultura popular". En: Feminism, Femininity and Popular Culture, p.130-151. Manchester: Manchester University Press.

LENARDUZZI, V. (2012). Placeres en movimiento: cuerpo, música y baile en la escena electrónica. Buenos Aires: Aidos.

LINS LIMA, M. (2016). Religiosidade campo feminino sacro na performance de Madonna1. Intercom- 
Sociedade Brasileira de Estudos Interdisciplinares da Comunicação, XXXIX Congresso Brasileiro de Ciências da Comunicação. São Paulo: 05-9/09/2016.

LISKA, M. (2019). “La banda de sonido del movimiento de mujeres”. En: RINCÓN, O. (Comp.) La reinvención de lo popular: 45-61. Buenos Aires: La Crujía

------. Entre géneros y sexualidades. Tango, baile y cultura popular. Buenos Aires: Caserola, M. (2018).

MCCLARY, S. (1991). Feminine Endings: Music, Gender, and Sexuality. Minnesota: University of Minnesota Press.

VIOTTI, N.; FELITTI, K. (2016). “El cielo las hará libres. Mía Astral, astrología y feminismo new age”. Revista Anfibia, 15/06/2016.

VIOTTI, N.; FUNES, M.E. (2015). "La política de la nueva era: el arte de vivir en Argentina”. Debates do Ner, Porto Alegre 16 (28), p.17-36. 